\title{
Inhibition of glutamine uptake regulates mTORC1, glutamine metabolism and cell growth in prostate cancer
}

\author{
Qian Wang ${ }^{1,2}$, Rae-Anne Hardie ${ }^{1,2}$, Seher Balaban ${ }^{3}$, Mark Schreuder ${ }^{3}$, Andrew Hoy ${ }^{3,4}$, Michelle van Geldermalsen ${ }^{1,2}$, \\ Ladan Fazli ${ }^{5}$, Rajini Nagarajah', Charles Bailey ${ }^{2,6}$, John Rasko ${ }^{6,7}$, Jeff Holst ${ }^{1,2^{*}}$
}

From Metabolism, Diet and Disease 2014: Cancer and metabolism

Washington DC, USA. 28-30 May 2014

\section{Background}

Amino acids such as glutamine are important for tumor cell growth, survival and metabolism. There is renewed interest in glutamine metabolism due to the importance of reductive carboxylation in cancer. The amino acid transporter ASCT2 (SLC1A5) mediates uptake of glutamine in cancer cells. We have recently reported that ASCT2 expression is significantly upregulated in melanoma, and ASCT2 inhibition significantly decreases glutamine uptake, cell growth, cell cycle and mTORC1 pathway activation [1]. We have previously shown that ASCT2 expression is regulated by the androgen receptor in prostate cancer [2], and in this current study we further examine ASCT2 expression levels in prostate cancer. Our specific aim was to determine the impact of inhibiting ASCT2-mediated glutamine uptake and metabolism on cell growth.

\section{Materials and methods}

We have assessed the role of ASCT2 in prostate cancer using: (1) tissue microarray analysis of ASCT2 protein expression in patients before and after neoadjuvant hormone therapy, (2) cell lines (LNCaP and PC-3) and (3) xenograft (PC-3) models in vivo. Glutamine uptake, cell growth, cell cycle, mTORC1 pathway and glutamine metabolism pathways were assessed using a variety of ASCT2 inhibitors and shRNA mediated ASCT2 knockdown.

\section{Results}

ASCT2 is highly expressed in primary prostate cancer, but levels decrease after neoadjuvant hormone therapy, before increasing again in recurrent disease. Inhibition of ASCT2 function by benzylserine led to decreases in glutamine uptake, glutamine metabolism (oxygen consumption rate, glutamine oxidation and lipogenesis), cell cycle progression, mTORC1 pathway activation and cell growth. These data were confirmed after shRNAmediated ASCT2 knockdown in vitro. Furthermore, shRNA knockdown in PC-3 cell xenografts led to a significant reduction in tumor growth in vivo.

\section{Conclusions}

ASCT2-mediated glutamine uptake is essential for multiple pathways including glutamine metabolism and mTORC1 signaling, thereby regulating cellular energy, protein synthesis and cell growth. As such, ASCT2 is a putative therapeutic target in prostate cancer.

\begin{abstract}
Authors' details
'Origins of Cancer Laboratory, Centenary Institute, Camperdown, NSW, Australia. ${ }^{2}$ Sydney Medical School, University of Sydney, NSW, Australia. ${ }^{3}$ Discipline of Physiology, Bosch Institute, University of Sydney, NSW, Australia. ${ }^{4}$ Boden Institute of Obesity, Nutrition, Exercise \& Eating Disorders, University of Sydney, NSW, Australia. ${ }^{5}$ Department of Urologic Sciences, University of British Columbia, Vancouver, BC, Canada. ${ }^{6}$ Gene and Stem Cell Therapy Program, Centenary Institute, Camperdown, NSW, Australia. ${ }^{7}$ Cell and Molecular Therapies, Royal Prince Alfred Hospital, Camperdown, NSW, Australia.
\end{abstract}

Published: 28 May 2014

References

1. Wang Q, Beaumont KA, Otte NJ, Font J, Bailey CG, van Geldermalsen M, Sharp DM, Tiffen JC, Ryan RM, Jormakka M, Haass NK, Rasko JEJ, Holst J: Targeting glutamine transport to suppress melanoma cell growth. Int J Cancer 2014, Epub 17 Feb.

Origins of Cancer Laboratory, Centenary Institute, Camperdown, NSW,

Australia

Full list of author information is available at the end of the article 
2. Wang Q, Tiffen J, Bailey CG, Lehman ML, Ritchie W, Fazli L, Metierre C, Feng Y, Li E, Gleave M, Buchanan G, Nelson CC, Rasko JEJ, Holst J: Targeting amino acid transport in metastatic castration-resistant prostate cancer: Effects on cell cycle, cell growth and tumor development. J Natl Cancer Inst 2013, 105:1463-1473.

doi:10.1186/2049-3002-2-S1-P27

Cite this article as: Wang et al:: Inhibition of glutamine uptake regulates mTORC1, glutamine metabolism and cell growth in prostate cancer. Cancer \& Metabolism 2014 2(Suppl 1):P27

Submit your next manuscript to BioMed Central and take full advantage of:

- Convenient online submission

- Thorough peer review

- No space constraints or color figure charges

- Immediate publication on acceptance

- Inclusion in PubMed, CAS, Scopus and Google Scholar

- Research which is freely available for redistribution

Submit your manuscript at www.biomedcentral.com/submit
() Biomed Central 